\title{
Factors retarding the development of school libraries in North Central Nigeria
}

\author{
Columbus Udofot, $P h D, C L N$ \\ Department of Library and Information Science \\ Benue State University \\ Makurdi, Nigeria \\ E-mail: columbusudofot@yahoo.com \\ Cell: +2348035637958 \\ Joy Asibi Idachaba, $P h D$ \\ Federal University of Agriculture, Makurdi, Nigeria \\ E-mail: idachabajoy@yahoo.com \\ Cell: +2348059632740
}

\begin{abstract}
This study was conducted in secondary schools libraries to ascertain the factors retarding the development of school libraries in North Central Nigeria and to proffer suggested strategies to overcome them. The researchers used two research questions to guide the study which adopted the descriptive survey design method. A total of 10 secondary schools were used as sample with 8 respondents comprising the Principal, a Teacher Librarian and 6 other teachers were used as respondents in each school. The main instrument for data collection was questionnaire while data collected were analyzed using the simple frequency and percentage table. The findings highlight lack of accommodation, inadequate funding in school libraries in Nigeria, as well as inadequate provision of library resources and services, amongst others, as factors retarding the development of school libraries. The study recommends some measures that would enhance the development of school libraries to include proper awareness creation, recruitment of qualified staff as well as sufficient funding of the libraries.
\end{abstract}

Keywords: Factors retarding, School libraries, North Central, Nigeria

\section{Introduction}

The concept of education is defined by Fafunwa, as cited in Nyam (2002), as the aggregate of all the processes by which a child or young adult develops the abilities, attitudes and other forms of behaviour which are of positive value to the society in which the child lives. Looking at this alone one can say that education is a vital element in the development of the individual. Western education is said to have started in Nigeria in the year 1882 (UNESCO 2004) but school at that time were not known to own libraries. However, as the concept of education began to change and at the same time the change in intellectual content of school curriculum started improving, there arose the need for libraries in schools.

School libraries have been described as a collection of wide variety of learning and teaching materials which are housed in a place and centrally organized by qualified staff and indexed to save time (Waite, 2005).According to Gojeh (2004) school libraries are buildings established at primary and secondary schools with trained personnel, organized book and non-book materials that are provided for use by student and staff of the school. Ozinwa (2009) pointed out the core values and objectives of school libraries to include acquiring, process and making available to pupil and student, a wide range of books and other materials to supplement and enrich the teaching and learning situation in schools. This is why Edegin (2001) opined that to maintained quality and quantity on what is taught in the Universal Basic Education (UBE) programme, proper and adequate school library development plan should be embarked upon. At primary and secondary school levels, the development of library to 
Columbus Udofot and Idachaba Joy Asibi: Factors retarding the development of school libraries in North Central Nigeria

enhance teaching and learning of the younger ones is pertinent.

Development of school libraries varies from one country to another. In Jamaica, for instance, Henry (2002) reported that school libraries were at a developing stage portraying inadequacies in funding, staffing, physical facilities and the services provided. In South Africa, especially in Tonga, school libraries development which dates back to the 1960s has not made significant improvement. This shows that the development of school libraries is not smooth even at international level.

In Nigeria, the defunct western Nigerian regional government took the initiative in 1955 to introduce a school library scheme to supplement its free education programme but due to improper planning and implementation, the scheme collapsed shortly after the introduction (Cork, 2008). The 1960s decade witnessed few schools and fewer schools libraries in Nigeria due to lack of fund and Lukewarm attitudes of some church missionaries who owned greater percentages of the schools in the country. However, with the takeover of the schools by the government in 1970s, there was a greater recognition of the educational role of the school library. This recognition was expressed in the national policy on education of 1977. This acknowledgement highlighted the indispensable role of the school libraries. Consequently, for the first time, some administrators were made to provide libraries in schools. It was not until 1972 that the federal government took the first positive step by inviting UNESCO to advise her on how to develop school libraries (UNESCO, 2004).

Coming to North Central Nigeria, the journey of the school library development has not been very smooth. According to Utor (2006) school libraries in Nigeria particularly in the North Central states are managed by unqualified persons with graduates of library science teaching in those schools. Supporting this view, Ofoada (2017) averred that libraries in some schools are run by unqualified staff which doesn't augur well for the development of school libraries.

The foregoing presupposes that there are factors affecting the development of school libraries. These factors can either facilitate or retard the development of school libraries. This research work seeks to highlight the factors retarding the development of school libraries in North Central Nigeria and suggest ways of ameliorating them.

School libraries are collection of books and other relevant materials which are organized and are housed in a building with the emphases of supporting the curriculum of that particular school. The collection of school library has variety of learning and teaching materials, which are housed in a place and centrally organized to serve the pupils, students and staff. The materials stocked include books, periodicals, films, slide, tape, journals etc. Supporting the above view Nyam (2002) noted that, the establishment of school libraries is as essential as the establishment of schools themselves. The literature has, however, thrown up certain factors as hindrances to the development of school libraries.

According to Elaturoti (2000), lack of accommodation and standard space, the display area of reading, work room, among other facilities are identified as the important factors retarding the development of library in schools. Dike (2001) supported Elaturoti's view when she opined that lack of accommodation is the most important factor retarding the development of schools libraries. Both of them have agreed that space and accommodation are vital element for a library.

Kolawole (2011) likened school library to a playground waiting to be explored with the Librarian as the playmate but cited lack of the qualified Librarians to explore this ground (the library) as a 
Columbus Udofot and Idachaba Joy Asibi: Factors retarding the development of school libraries in North Central Nigeria

problem. In their contribution, Agabi (2003) and Akpe (2005) opined that lack of nonprint materials in school libraries is also a major factor that retard the development of school libraries. They further submit that non print materials make learning concrete and real and they listed them to include pictures, posters and models. But argue that these nonprint materials are lacking in our libraries.

Furthermore, Bawa (2003) added lack of coherent policy on the provision of school libraries in most of the African countries as another factor retarding the development of school libraries.

Adequate funding is necessary in the development of any venture. Inadequate funding has been a bane of school library development especially in Nigeria. According to Utor (2006) school libraries have become resource centers for both teachers and students and are regarded as educational facilitator although most states in Nigeria only pay lip services to the development of school libraries.

Various strategies have been suggested by scholars on how to enhance development of school libraries. Utor (2006) asserted that all primary and post primary schools must, as a matter of urgency, have functional libraries whose materials must include books and non-book resources. Agreeing with Utor, Daniel (2001) opined that proprietors of schools are required to provide functional libraries in all their educational institutions.

In her contribution, Dike (2001) averred that accommodation for school library and favorable conditions to maintain the collection, good ventilation, enough light and structures should be adequately put in place. To Dike, when all these are put in place, school library development is enhanced. Egesimba (2011) submitted that for proper school library development to be enhanced, sufficient awareness must be created. In his view, most administrators of schools do not value the role of school library in their educational process because of lack of awareness. Therefore, awareness creation as a strategy is the most important element in solving the problems of school library development in Nigeria.

Funding has also been suggested as a factor that can enhance library development. Olorumboba and Bolarinwa (2005) submitted that funding is necessary for the proper functioning of the school libraries and that every state ministry of education should provide funds for the establishment of libraries. To them therefore, if the education ministries provide funds for smooth running of the school libraries, the problem of low library development would then become a thing of the past. On the need for staffing, Utor (2006) declared that government and those concerned must ensure that qualified staff is recruited to manage the school libraries. This, according to him, would enhance the smooth and proper functioning of the school library.

\section{Methods}

The researchers adopted the descriptive survey design for the study. According to Nworgu (2006), descriptive survey is one that is aimed at collecting data on, and describing in a systematic manner the characteristics, features or facts about a given population. The rationale for using descriptive survey is based on the fact that it enabled better investigation of the subject under study. The population comprised 10 functional secondary schools in the area of study. In each school, 8 respondents were randomly picked to include the principal, a teacher librarian and 6other teachers who were sampled as respondents. Therefore, a total number of 80 respondents were drawn from the 10 selected secondary schools.

The data collection instrument for the conduct of the study was the questionnaires and the data collected were analyzed using frequencies and percentage. 
Columbus Udofot and Idachaba Joy Asibi: Factors retarding the development of school libraries in North Central Nigeria

\section{Results}

A total of 80 questionnaires were administered on respondents and 76 were returned and found usable.
Research question one: What factors retard the development of schools libraries in North Central Nigeria?

The data in Table 1 are used to answer this question.

Table 1: Factors retarding school library development

\begin{tabular}{|c|c|c|c|c|c|c|c|c|c|}
\hline \multirow[t]{2}{*}{ Factors } & \multirow{2}{*}{$\begin{array}{l}\begin{array}{l}\text { Very } \\
\text { extent }\end{array} \\
\text { No }\end{array}$} & \multirow{2}{*}{$\begin{array}{l}\text { great } \\
\%\end{array}$} & \multicolumn{2}{|c|}{ Great extent } & \multicolumn{2}{|c|}{ Low extent } & \multicolumn{2}{|c|}{$\begin{array}{r}\text { No } \\
\text { extent }\end{array}$} & \multirow[t]{2}{*}{ Total } \\
\hline & & & No & $\%$ & No & $\%$ & No & $\%$ & \\
\hline $\begin{array}{l}\text { Lack of } \\
\text { Accommodation }\end{array}$ & 37 & 48.68 & 27 & 35.53 & 10 & 13.16 & 2 & 2.63 & 76 \\
\hline $\begin{array}{l}\text { Poor budgetary } \\
\text { allocation }\end{array}$ & 41 & 53.84 & 24 & 31.58 & 6 & 7.89 & 5 & 6.57 & 76 \\
\hline $\begin{array}{l}\text { High cost of } \\
\text { books }\end{array}$ & 24 & 31.58 & 25 & 32.89 & 24 & 31.58 & 3 & 3.95 & 76 \\
\hline Lack of staff & 26 & 34.21 & 24 & 31.58 & 20 & 26.32 & 6 & 7.89 & 76 \\
\hline Lack of funding & 27 & 35.53 & 30 & 39.47 & 11 & 14.47 & 8 & 10.53 & 76 \\
\hline $\begin{array}{l}\text { Lack } \\
\text { awareness }\end{array}$ & 40 & 52.63 & 16 & 21.05 & 10 & 13.16 & 10 & 13.16 & 76 \\
\hline
\end{tabular}

Research Question Two: What are the strategies that could enhance the development of school libraries in North Central Nigeria?
The data in Table 2 are used to answer this question. 
Columbus Udofot and Idachaba Joy Asibi: Factors retarding the development of school libraries in North Central Nigeria

Table 2: Strategies that would enhance the development of school libraries in North Central Nigeria

\begin{tabular}{|c|c|c|c|c|c|c|c|c|c|}
\hline \multirow[t]{2}{*}{ Strategies } & \multirow{2}{*}{$\begin{array}{l}\text { Very } \\
\text { extent } \\
\text { No }\end{array}$} & great & \multicolumn{2}{|r|}{$\begin{array}{l}\text { Great } \\
\text { extent }\end{array}$} & \multicolumn{2}{|c|}{ Low extent } & \multicolumn{2}{|c|}{ No extent } & \multirow[t]{2}{*}{ Total } \\
\hline & & $\%$ & No & $\%$ & No & $\%$ & No & $\%$ & \\
\hline $\begin{array}{l}\text { Provision of } \\
\text { funds for } \\
\text { library } \\
\text { development }\end{array}$ & 58 & 76.32 & 10 & 13.16 & 4 & 5.26 & 4 & 5.26 & 76 \\
\hline $\begin{array}{l}\text { Instruction in } \\
\text { library } \\
\text { use/awareness } \\
\text { creation }\end{array}$ & 19 & 52.65 & 40 & 52.65 & 10 & 9.21 & 7 & 9.21 & 76 \\
\hline $\begin{array}{l}\text { Recruitment of } \\
\text { qualified staff }\end{array}$ & 37 & 48.65 & 28 & 36.84 & 7 & 5.26 & 4 & 5.26 & 76 \\
\hline $\begin{array}{l}\text { Availability of } \\
\text { selection tools }\end{array}$ & 23 & 30.26 & 31 & 40.79 & 18 & 5.26 & 4 & 5.26 & 76 \\
\hline $\begin{array}{l}\text { Adequate } \\
\text { bibliographical } \\
\text { coverage }\end{array}$ & 21 & 27.63 & 30 & 39.47 & 19 & 11.84 & 9 & 11.84 & 76 \\
\hline $\begin{array}{l}\text { Non diversion } \\
\text { of funds meant } \\
\text { for library } \\
\text { development }\end{array}$ & 40 & 52.63 & 15 & 19.74 & 12 & 11.84 & 9 & 11.84 & 76 \\
\hline
\end{tabular}

\section{Discussion}

Based on the analysis of the research question one, the study has identified among other factors, lack of accommodation as one of the major factors retarding the development of school libraries. Other factors identified include high cost of books, lack of adequate staff, inadequate funding amongst others as factors retarding the development of school libraries in North Central Nigeria. These finding agreed with findings of some scholars like Elaturoti (2011); Ayorinde (2005); and Olorumtoba and Bolarinwa (2005) who found that lack of accommodation, inadequate space and inadequate funding are some factors retarding school library development in Nigeria.
From research question two, findings indicates that adequate funding, recruitment of qualified staff and creating awareness about the library amongst others, are strategies that could enhance the development of school libraries in North Central Nigeria. This finding is in agreement with Bolarinwa (2005); Utor (2006) and Egesimba (2011) who submitted that for proper school library development to occur, there should be sufficient awareness creation, government and those concerned must ensure that qualified staff are recruited and adequate funds meant for school library development must be provided. 
Columbus Udofot and Idachaba Joy Asibi: Factors retarding the development of school libraries in North Central Nigeria

\section{Conclusion}

This research work has revealed that despite the laudable benefits and support school libraries give to students and staffs, school libraries are the most neglected aspect of education in North Central Nigeria. The study further revealed factors that retard the development of school libraries to include lack of accommodation, lack of funding and inadequate staffing among other factors.

Based on the analysis of the research findings and conclusion, the following recommendations are made:

1. Development of school libraries should not be left in the hands of proprietors alone. Parents and other well-meaning individuals in the zone should contribute their quota.

2. Adequate budgetary allocation should be made for the procurement of relevant resource and materials in the library.

3. Teachers should encourage and inculcate in students the habit of reading and the use of the library.

4. Diversion of funds that are meant for the development of library in the zone should be discouraged.

5. There is the need to train and employ more qualified professional librarians to manage school libraries.

6. There is also the need for proper awareness creation inform of library education to both the staff and students of schools in the zone.

\section{References}

Agabi, I.C.(2003). Meeting the needs of school libraries in Nigeria.Nigerian Library and Information Science Review 2(3): 32-41.

Akpe, C. J. (2005). Libraries and school development. Information Research, 9(3), 232-244.
Ayorinde, S. (2005). Libraries not antiquities please Lagos. The Punch, March, 22. 3.

Bawa, P.T. (2003). Students information needs. Journal of Library and Information Science 4(182), 5973.

Cork, M. D. (2008). Library services and expectation of users. New York: Becker and Mayer.

Daniel, S. T. (2001). Students behaviour. Information Science 3(1), 49-55.

Dike, V. W. (2001). Library resources in education. Nigerian Libraries, 6(4), 65-78.

Edeginhere, M. N. (2001). Information needs of secondary school students. Lagos Journal of Library and Information Science 4(2), 60-76.

Egesimba, N.M, et al (2011). Adequate materials as pre-requisite functional school library. Mediterranean Journal of Social Science 2 (4): 11-25.

Elaturoti, J. E. (2000). Modeling information seeking. Library Quarterly 6(2), 161-183.

Gojeh, T. G.(2004). Libraries as school developers. Journal of Nigerian Library Association, Anambra State Chapter 5(2): 71-82.

Henry R. (2002). Dilemma of development: school libraries in Jamaica. Unpublished DLS Thesis, Columbia University, USA.

Kolawole, M. T. (2011). Information needs of school children in Ibadan.Lagos Journal of Library and Information Management 2(2), 16-34.

Nworgu, B. G. (2006). Educational research: Basic issues and methodology. Ibadan: Wisdom.

Nyam, S.S (2002). Introduction to history of education for colleges of education in Nigeria. Makurdi: Saint Press Ltd. 
Columbus Udofot and Idachaba Joy Asibi: Factors retarding the development of school libraries in North Central Nigeria

Ofoada, B.D. (2017). developing school libraries to standard. information Science, 3(4), 4854.

Olorumtoba, S. H. \& Bolarinwa, A.S. (2005). Schools anticipated information needs. Information Research, 9(1), 124-137.

Ozinwa, R.U. (2009). Information seeking behaviour of school children.
Journal of Library, Archival and Information Science 2(7): $88-96$.

UTOR,J.K (2006). Library education and national development. Makurdi: Onaivi Pub.

Waite, V.N. (2005). Dictionary of information science. London: Libraries Unlimited. 